\title{
The Raisin Industry in the Northern Cape Province, South Africa
}

\author{
Danny Calitz* \\ Independent Agricultural Consultant, Calitz \\ *Corresponding Author: Danny Calitz, Independent Agricultural Consultant, Calitz.
}

Received: July 18, 2019; Published: August 16, 2019

DOI: 10.31080/ASAG.2019.03.0618

\begin{abstract}
This informative article presents the reader with an indepth overview of the raisin industry in South Africa. It will cover the chain from since the first grape vine that was planted during 1659 by Jan van Riebeeck up to the current 2018/19 growing season.

South African Raisins is in huge demand in the world market due to ideal growing and drying conditions in the main growing areas - Orange River basin and the Olifants River region.

Raisins are primarily made from the Thompson and sultana grapes (vitis vinefera), but also of a range of tablegrape varieties and lately a legion of new cultivars flooded into vineyards of the raisin producing areas.

SA produces around 65-70,000 metric tons of raisins annually. The majority of which are being exported. Europe are the biggest buyer of SA Raisins and account for about 90 percent of the exported raisins.
\end{abstract}

Keywords: Raisins; Grapes; Vitis Vinefera; Orange River; Olifants River

\section{Introduction}

Traditionally dried fruit such as dates, apricots, apples and raisins have been a staple to people from the Mediterranean regions for millenia. This include the areas: Iran, Iraq, Turkey, Syria, Israel, Lebanon and Egypt. Drying foods have long since been an effective way to preserve foods that would otherwise had to be eaten when ready. These areas are blessed with hot, warm sun, thus making it the perfect food dryer. Early hunter/gatherers observed these foods drying in the sun, not spoiling and keeping their edible form. Once tasted they also found them stable and very much concentrated with flavour, colour and sweetness. They also found their energy to be quick releasing, making it the perfect traveling/trekking food.

Genus Vitis and Species Vinifera from the family Vitaceae grapes, have been cultivated since the beginning of time. In the Christian Bible it is mentioned from the beginning and in historical drawings, on wall carvings and decorations, etc. its worth and goodness is advertised throughout the 'old world'.

When South Africa was colonised in 1652 by the DEIC (Dutch East India Company, VOIC-Vereenigde Oost-Indische Compagnie) under Jan van Riebeeck, he brought plants from Europe with him and in 1672 the first grape vines were planted in Great Constantia (a farm that belonged to the Governor of the Cape.) From here it quickly spread with the farmers as they moved inland and up- wards. In the Northern Cape, farmers started off by farming extensively with cattle and sheep as it is still done nowadays.

The early inhabitants (the Kwa, the Khoi and the San people) called it the Xhariep or Gariep. The Dutch called it the Groot Rivier (The Great River). It was later changed to the current Orange River by Colonel Robert Gordon (Commander of the Dutch East India Company garrison in the Cape). He was on a inland in 1779 , and he named it in honour of William $\mathrm{V}$ of Orange.

The Orange River starts in Lesotho, (Maloti Mountains) where it is called the Senque, at a hight of around 3,350 metres above sealevel. It mouths into the Atlantic ocean at Alexander Bay on the West coast of South Africa some 2,200 kilometers further.

The Orange River has a catchment area of some 973,000 $\mathrm{km}^{2}$ and the major feeding vein is the Vaal River that comes from the Gauteng Highveld and empties into the Orange at Barclay West.

As said, the majority of the farmers in the Northern Cape area were extensively farming with animals, sheep and cattle. But, by 1896/97 there was a large epidemic of rinderpest amongs the animals as a result of severe draughts. Farmers were going bankrupt and the Dutch Reformed Church (the church of the majority of the white South Africans in that time) decided to help the farmers by giving them land all along the Orange River. 
So, in 1897 the Dutch Reform Church started a white farmers colony on the farms Soetap (Sweet tap) and Kakamas on the banks of the Orange River.

In order to utilise the water from the river, there needed to be canals to transfer the water so the farmers started building these. Sometimes through the hard rock of the area with not much more than picks and shovels, under the ingenious leadership of people like Mr. Japie Lutz and Mr. Piet Burger who respectively was in charge of the water tunnels and the water wheel (a device that is used to get water from the canals onto the lands and fields.

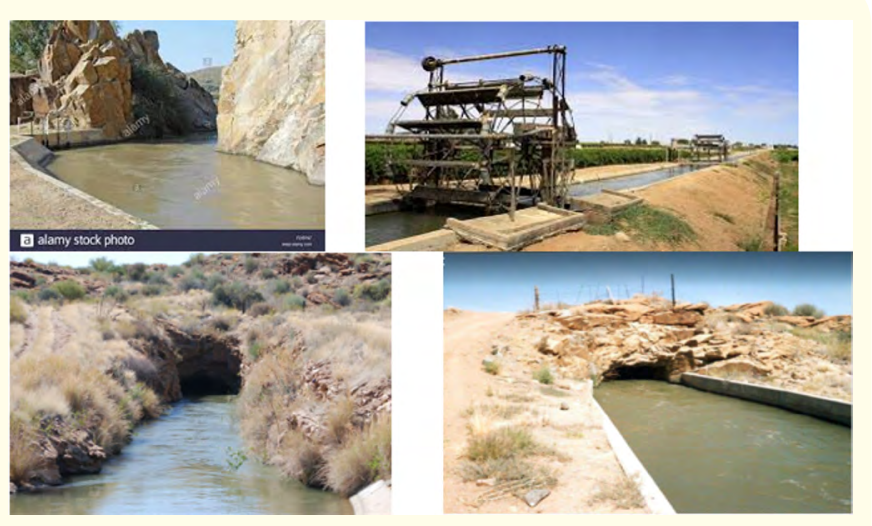

Figure 1

The qualified engineers critisized their methods, but the farmers kept building until they made it into a workable network of canals that are still today serving the farms with irrigation water. The bigger islands in the river was also cleaned by hand, donkeys and oxen. These were transported across the river by ponds. Farmers would then built small dams, fill it with water then break the walls so that the land could be flooded, thereby creating a level surface.

Each farmer was awarded around 6 morgen (Equal to about 5.1 Hectares), as well as a site where they could build a house, and in the beginning the farmers mostly planted peas, beans and lucern (Alfalfa). The peas and beans were sold to co-ops as dried products whilst the lucern was also sold to co-ops, but to be used as animal fodder. The church, by means of the colony committee, strictly enforce that the selling of the produce only went throught the co-ops and could not be sold by the farmers themselves.

In 1922 the first raisin-bearing vines were planted by Mr. P.J. Cellie. He was the then chairperson of the Labour Colony Kakamas (AKK-Arbeids Kolonie Kakamas). The vines flourished in the Kakamas area and by 1933 a total of 451 Metric tons were already produced. This was a time when the alfalfa was a main crop (with wheat and maize) and vines had to compete as an income where cash was king.

By 1944 a total of 1,100 mt was produced. In the next few years it went down a bit as the alfalfa prices soared. But it gradually picked up again - In 2017/18 the total raisins harvested in South Africa was around 70,000 mt.

In 1937 the South African Government, which was still a Union under Great Brittain, introduced the single channel marketing under the Control Boards Act. (In the case of raisins it was the South African Dried Fruit Board). This, in short, stated that all raisins can only be marketed through this body and no-one is allowed to deal with any buyer on his/her own.

This continued until 1997 when the multi-channel marketing was introduced. This paved the way for other roleplayers like South African Raisins (PTY) Ltd., Redsun Raisins (PTY) Ltd. and others to join in the lucrative raisin industry in South Africa. With competition came better produce prices for the farmers as well and they as producers can now also enjoy better prices for their produce and they can even 'shop' for an even better price from other companies/buyers.

South Africa has no price support policies for raisin producers, but Government did establish a statutory levy payable by dried fruit producers to provide financial support to the Dried Fruit Technical Services (DFTS) for functions deemed essential to the industry, namely research, training, plant improvement and development of the raisin industry.

\section{Grape cultivars for raisins}

Raisins is a grape grown on a vine and when ripe starts to dry out. So, in effect, raisins can be made from any grapes being destined for wine, table or product specific grapes for raisins. Commercially farmers use the following:

1. Thompson seedless vines

2. Merbein seedless

3. Sultana seedless

4. Salma Pete seedless

5. Diamond Muscat seedless

6. Summer Muscat seedless

7. Black Monukka seedless

8. Flames seedless

9. Festival (Sugra 16) seedless - From table grape packhouse (quality that are not cleared for export)

10. Zante Currents seedless

11. Muscat d' Alexandira seeded

12. Datal seedless

13. Sugra 39 seedless

14. Dovine seedless

15. Arra 14 seedless

16. Arra 15 seedless

Thompson/Sultanine are still the largest supplier to the raisin industry, but the newcomers are making their marks whilst 'older culitvars, like Black Monukka and Datal are being phased out. 
There are about 1,100 raisin producers and seven major raisin processors and packers in South Africa.

The area planted with grapes for raisin production will increase by 3 percent to 17,500 hectares in the 2018/19 season, from the 17,000 hectares in the $2017 / 18$ season.

\section{Types of raisins}

In South Africa, and moreso in the Kakamas area, they have the four main types of raisins and then also about 3-4 'sub-types' or commercial types of raisins:

1. Sundried raisins just called Thompson Sundried

2. Lye/bleached raisins (OR and WP Raisins -Orange River and Western Province Raisins)

3. Sulphered raisins called Goldens

4. Currents (a small Greek current that is mainly harvested in the Olifants River region and then transported to factories in the Northern Cape.)

5. Sub-type Flames (Flame table grapes that is sundried)

6. Sub-type Cherry Flames (Flame table grapes that were treated with sulpher and comes out a pinkish/cherry colour)

7. Cake Mix (A legion of standard grades mixes of the above sometimes orange peel are added) Usually worked into fruit cakes and breads

8. Bakers mix (usually the same as above, but without the adding of orange and/or other fruits)

9. Hereunder from L to R: Sundried, Goldens, Flame Jumbo, OR and Bakers Mix
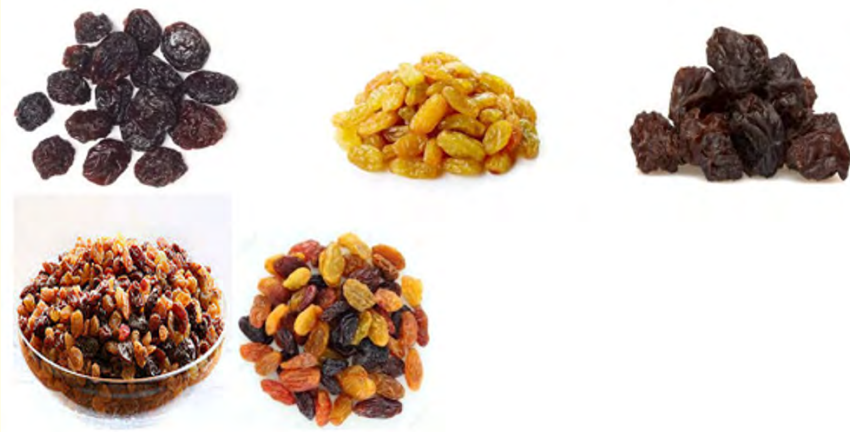

Figure 2

These are found in three quality categories:

1. Choice Grade

2. Standard Grade

3. Industrial Grade

All of these are then also found in different sizes. Sizing are done on mesh screens in the factory, but are expressed as a count number per 100 grams of raisins.
1. Jumbo Jumbo: Up to 100 raisins per 100 gram

2. Jumbo: 100 to 130

3. Bold: 130 to 230

4. Medium : 230 to 290

5. Small: 290 to 400

6. Midget: More than 400 raisins per 100 gram

\section{How are they MADaE}

The sun, wind and dry climate are the three biggest factors needed to make good raisins. Only one type of raisin utilises direct sunlight to dry the grapes, whereas the other two, OR/WP and Goldens need warm dry windflow to dry the grapes.

\section{Sundried raisins}

1. Grapes are picked at a optimum sugar of around 22-27 Brix (Degrees Brix (symbol ${ }^{\circ} \mathrm{Bx}$ ) is the sugar content of an aqueous solution. One degree Brix = 1 gram of sucrose in 100 grams of solution.

2. Grapes are transported in a plastic lug (picking crate of around $20-25 \mathrm{~kg}$ ) to the drying areas. Traditionally this was large cement slabs or flat rock aeas that was cleaned and dustfree. Nowadays farmers also use netted strips that are raised about $400-500 \mathrm{~mm}$ off the ground. This assists the drying process and cuts down on labour, as it is not necessary to 'turn' the raisins.

3. When grapes are dried on the cement slabs, they need to be turned as soon as they are tough enough to be handled. At this stage they are still on the bunch and stays that way until they are picked up.

4. After about 10-12 days of hot sun and dry weather the raisins is dried to around $14-16 \%$ moisture content. This is the opitimum for the processors.

5. As they are picked up, the bunches are rubbed as to loosen the raisins from the bunches. This helps to lessen the 'OfNo-Value' percentage from the grading and thereby up the paid percentage of their product.

6. Raisins are then accumilated in bulk bins (usually wooden bins of around $1 \mathrm{~m} \times 1.2 \mathrm{~m} \times 0.7 \mathrm{~m}$ and holds about 400 $450 \mathrm{~kg}$ of raisins). These belongs to the processors and are 'loaned' to the suppliers (farmers).

7. These bulk bins are now transported to the processors where it is weighed, inspected and classed into the three grades. Farmers/suppliers are then paid according to these grades. (ex. If a farmer delivers $100 \mathrm{~kg}$ and $80 \%$ is choice $/ 10 \%$ standard grade $/ 8 \%$ industrial $/ 2 \%$ Of-No-Value, he will receive $80 \mathrm{~kg} x$ the choice grade buy-in price/10 $\mathrm{kg} x$ the standard grade buy-in price and $8 \mathrm{~kg} x$ the industrial buy-in price. The last $2 \mathrm{~kg}$ he does not get paid for, as it has no value (usually damaged raisins, sticks, stones, etc. 


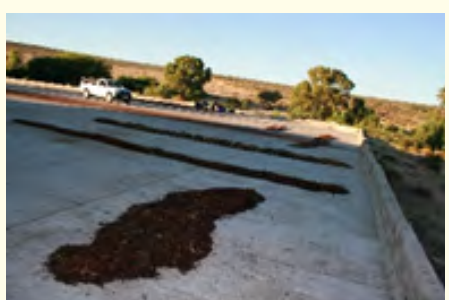

Figure 3

\section{OR Raisins}

1. OR or Orange River Raisins are typical raisin grapes picked a little earlier than the sundried type.

2. When picked at around 20-22 brix, it is taken to a working station where a lye solution is prepared by mixing Sultana oil with an alkaline base. This softens the skin by taking the outermost epidermis off.

3. Grapes are then spread out on a wire mesh bed that are stacked about $2 \mathrm{~m}$ high with about $50 \mathrm{~cm}$ gaps between beds. The top of this unit is covered with a corrugated iron roof. The sides of this unit are covered with a light tarp on the sun side to prevent the sun from having contact with the product.

4. The drying process takes about 21 days.

5. Around day 20 in the late morning (or the last day before the optimum dryness of $14-16 \%$ is reached), the raisins are put on cement slabs and lightly sprinkled with a water mist. It is now left to dry.

6. The above is to obtain the perfect OR raisin colours of light green to light amber. No greens of brown raisins is wanted in the product.

7. When dried, steps from step 5 above is followed

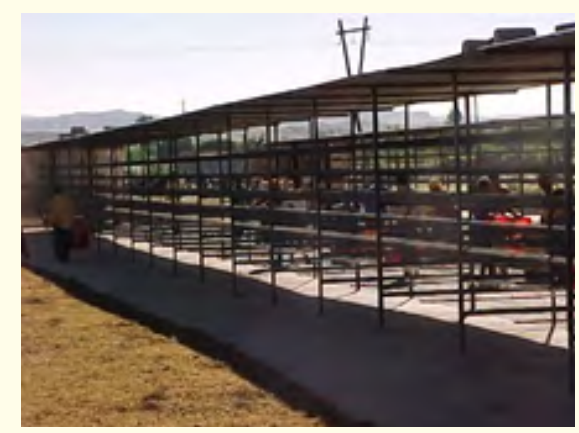

Figure 4: OR drying area in background with the cement slabs for "bleacing" the raisins.

\section{WP raisins}

1. Steps 1-2 is the same as above.

2. Grapes are laid on cement slabs after a lye treatment and left to dry.
3. Optimum dryness is obtained from around day 10-12.

4. The state and general appearance is the same as with OR, but the colour is much darker and uniformly brown.

5. Steps 5-7 the same as with Sundried.

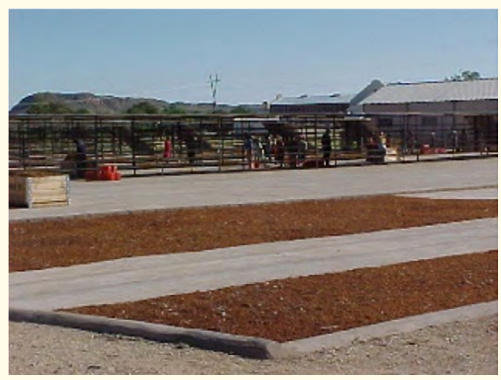

Figure 5: Bleached WP raisins in the making in the forefront.

Golden raisins

1. Grapes are picked with sugar levels around 18-20 brix.

2. Grapes are then dipped in the same lye solution as with OR and WP raisins.

3. Grapes are then packed on wooden trays that accomodate about $40 \mathrm{kgs}$. These trays are stacked with a $50 \mathrm{~mm}$ gap between trays that allows airflow. It is stacked 15 trays high.

4. These stacked trays are then placed in a 13 stack 'train'. This train is then covered with a tarp and sealed. Theses stacks are placed east to west as to make sure that no direct sunlight get in contact with the grapes.

5. $25 \mathrm{~kg}$ sulpher is then lit to smoke for 8 hours.

6. Thereafter the tarp is taken off and the grapes are left for about 21 days to dry.

7. If grapes are picked too green, the end product is also green.

8. When sun gets to the product is turn brownish in colour.

9. If the sugar is too high in the grapes, the raisins turns dark brown to black.

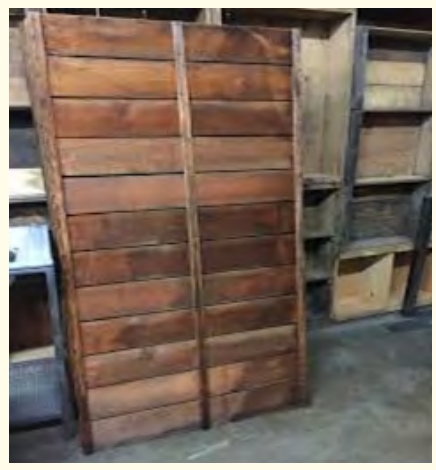

Figure 6: Wooden trays for drying. 


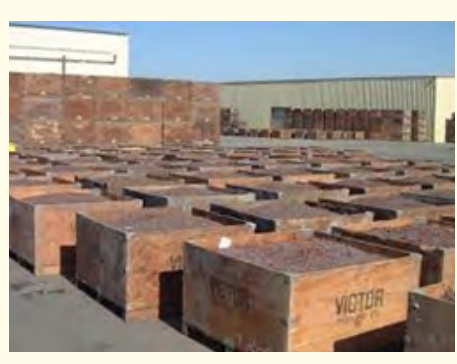

Figure 7: Wooden bulk bins.

The markets

- Growth of the South African raisin production continues.

- Post forecasts that raisin production will increase by 6 percent to 70,000 Metric Tons (MT) in the

- $2018 / 19$ season, from $66,100 \mathrm{mt}$ in the $2017 / 18$ season.

- About 90 percent of raisin production in South Africa is from the Orange River Region and 10 percent is produced in the Olifants River region, in the Western Cape Province. The Northern Cape Province is the main raisin production area, due to its ideal climate for drying grapes and availability of irrigation water from the Orange River.

- The Thompson Seedless raisin is the predominant cultivar produced in South Africa, and accounted for 55 percent of the total production in 2017, followed by the Goldens (32 percent).

The local consumption in South Africa will be around 14,900mt in the 2018/19 season. This constitudes a +-3\% increase from the previous season. This is due to a stronger health and snack food market.

South Africa exports about $80 \%$ of all raisins produced. The 2018/19 season shows about a $6 \%$ increase from the previous season to about $57,000 \mathrm{mt}$.

Germany is the largest single market and accounted for 26 percent in 2017 , followed by

- Netherlands (11 percent),

- United States (10 percent),

- $\quad$ Algeria (10 percent),

- $\quad$ Canada (8 percent),

- $\quad$ France (7 percent), and

- $\quad$ United Kingdom (6 percent).

Producer prices for raisins are very sensitive and rely on supply and demand factors, as well as the foreign exchange rate. Producers agree on price and sign supply contracts with raisin processors and packers in advance for each season. This usually comes to a bidding war between the different processors which works in favour of the farmer. With the coming of the multi channel marketing (dissolving of the Marketing control boards) saw the farmers with an almost hundred fold increase in their selling price.
Processors adhere to Policies and Regulations on Import Duties, Quality Standards and Labelling Regulations as well as Export Quality Regulations set by the South African Department of Agriculture, Forestry and Fisheries (DAFF). PPECB has a government mandate to do inspections at processors' site on every container load that are exported [1-9].

\section{Conclusion}

South African raisins are very nutritional and of a very high standard. It is a much sought after commodity on world markets and do enjoy premium prices.

The table hereunder shows the goodness of raisins.

\begin{tabular}{|c|c|c|}
\hline \multicolumn{2}{|c|}{$\begin{array}{l}\text { Raisins, seedless - Nutritional value per } 100 \mathrm{~g} \\
(3.5 \mathrm{oz})\end{array}$} & \\
\hline Energy & $1,252 \mathrm{~kJ}(299 \mathrm{kcal})$ & \\
\hline Carbohydrates & $79.18 \mathrm{~g}$ & \\
\hline Sugars & $59.19 \mathrm{~g}$ & \\
\hline Dietary fiber & $3.7 \mathrm{~g}$ & \\
\hline Fat & $0.46 \mathrm{~g}$ & \\
\hline Protein & $3.07 \mathrm{~g}$ & \\
\hline Vitamins & Quantity & $\% \mathrm{DV}^{\dagger}$ \\
\hline Thiamine (B1) & $0.106 \mathrm{mg}$ & $9 \%$ \\
\hline Riboflavin (B2) & $0.125 \mathrm{mg}$ & $10 \%$ \\
\hline Niacin (B3) & $0.766 \mathrm{mg}$ & $5 \%$ \\
\hline Pantothenic acid (B5) & $0.095 \mathrm{mg}$ & $2 \%$ \\
\hline Vitamin B6 & $0.174 \mathrm{mg}$ & $13 \%$ \\
\hline Folate (B9) & $5 \mu \mathrm{g}$ & $1 \%$ \\
\hline Choline & $11.1 \mathrm{mg}$ & $2 \%$ \\
\hline Vitamin C & $2.3 \mathrm{mg}$ & $3 \%$ \\
\hline Vitamin E & $0.12 \mathrm{mg}$ & $1 \%$ \\
\hline Vitamin $\mathrm{K}$ & $3.5 \mu \mathrm{g}$ & $3 \%$ \\
\hline Minerals & Quantity & \\
\hline Calcium & $50 \mathrm{mg}$ & $5 \%$ \\
\hline Iron & $1.88 \mathrm{mg}$ & $14 \%$ \\
\hline Magnesium & $32 \mathrm{mg}$ & $9 \%$ \\
\hline Manganese & $0.299 \mathrm{mg}$ & $14 \%$ \\
\hline Phosphorus & $101 \mathrm{mg}$ & $14 \%$ \\
\hline Potassium & $749 \mathrm{mg}$ & $16 \%$ \\
\hline Sodium & $11 \mathrm{mg}$ & $1 \%$ \\
\hline Zinc & $0.22 \mathrm{mg}$ & $2 \%$ \\
\hline Other constituents & Quantity & \\
\hline Fluoride & $233.9 \mu \mathrm{g}$ & \\
\hline \multicolumn{2}{|c|}{$\begin{array}{l}\text { Units } \mu \mathrm{g}=\text { micrograms } \\
\mathrm{mg}=\text { milligrams } \\
\mathrm{IU}=\text { International units }\end{array}$} & \\
\hline \multicolumn{2}{|c|}{$\begin{array}{l}\text { †Percentages are roughly approximated } \\
\text { using US recommendations for adults. } \\
\text { Source: USDA Nutrient Database }\end{array}$} & \\
\hline
\end{tabular}

Table 


\section{Bibliography}

1. W Sikuka. GAIN Report- Moderate growth of South Africa Raisins continues.

2. Internet report-Raisins industry of South Africa.

3. Agricultural Research Council of South Africa.

4. South African Fruit Trade Flow 11 (2013).

5. Izak Bouwer-The history of Kakamas Settlement

6. Grain SA-The De-regulating of Agricultural marketing and forming of Trusts

7. Wikipedia

8. www.Hortgro.co.za

9. Own knowledge gained from 12 years in the raisins processing industry.

Volume 3 Issue 9 September 2019

(C) All rights are reserved by Danny Calitz. 